\title{
Biocompatibility and setting time of CPM-MTA and white Portland cement clinker with or without calcium sulfate
}

\author{
Clovis Monteiro BRAMANTE ${ }^{1}$, Marcia Magro KATO ${ }^{2}$, Gerson Francisco de ASSIS $^{3}$, Marco Antonio Hungaro DUARTE ${ }^{4}$, \\ Norberti BERNARDINELI ${ }^{1}$, Ivaldo Gomes de MORAES ${ }^{1}$, Roberto Brandão GARCIA ${ }^{4}$, Ronald ORDINOLA-ZAPATA², \\ Alexandre Silva BRAMANTE
}

\begin{abstract}
1- DDS, PhD, Full Professor, Discipline of Endodontics, Department of Operative Dentistry, Endodontics and Dental Materials, Bauru School of Dentistry, University of São Paulo, Bauru, SP Brazil.

2- DDS, PhD in Endodontics, Department of Operative Dentistry, Endodontics and Dental Materials, Bauru School of Dentistry, University of São Paulo, Bauru, SP Brazil.

3- DDS, PhD, Full Professor, Discipline of Histology, Department of Biological Sciences, Bauru School of Dentistry, University of São Paulo, Bauru, SP, Brazil. 4- DDS, PhD, Associate Professor, Discipline of Histology, Department of Biological Sciences, Bauru School of Dentistry, University of São Paulo, Bauru, $\mathrm{SP}$, Brazil.
\end{abstract}

Corresponding address: Clovis Monteiro Bramante - Departamento de Dentística, Endodontia e Materiais Odontológicos - Faculdade de Odontologia de Bauru - Universidade de São Paulo - Al. Octávio Pinheiro Brisola, 9-75 - 17012-901 - Bauru - SP - Brasil - Phone: 55-14-32358344 - e-mail: bramante@fob.usp.br

Submitted: March 3, 2012 - Modified: January 4, 2013 - Accepted: January 4, 2013

\section{ABSTRACT}

$\mathrm{O}$ bjective: To evaluate the biocompatibility and the setting time of Portland cement clinker with or without $2 \%$ or $5 \%$ calcium sulfate and MTA-CPM. Material and Methods: Twenty-four mice (Rattus norvegicus) received subcutaneously polyethylene tubes filled with Portland cement clinker with or without $2 \%$ or $5 \%$ calcium sulfate and MTA. After 15 , 30 and 60 days of implantation, the animals were killed and specimens were prepared for microscopic analysis. For evaluation of the setting time, each material was analyzed using Gilmore needles weighing $113.5 \mathrm{~g}$ and $456.5 \mathrm{~g}$, according to the ASTM specification Number C266-08 guideline. Data were analyzed by ANOVA and Tukey's test for setting time and Kruskal-Wallis and Dunn test for biocompatibility at $5 \%$ significance level. Results: Histologic observation showed no statistically significant difference of biocompatibility ( $p>0.05$ ) among the materials in the subcutaneous tissues. For the setting time, clinker without calcium sulfate showed the shortest initial and final setting times $(6.18 \mathrm{~s} / 21.48$ s), followed by clinker with $2 \%$ calcium sulfate ( $9.22 \mathrm{~s} / 25.33 \mathrm{~s})$, clinker with $5 \%$ calcium sulfate $(10.06 \mathrm{~s} / 42.46 \mathrm{~s})$ and MTA $(15.01 \mathrm{~s} / 42.46 \mathrm{~s})$. Conclusions: All the tested materials showed biocompatibility and the calcium sulfate absence shortened the initial and final setting times of the white Portland cement clinker.

Key words: Dental material. Calcium sulfate.

\section{INTRODUCTION}

Mineral Trioxide Aggregate (MTA) has been used for surgical and nonsurgical treatment such as root-end filling, perforation repair, pulpotomy and apexification procedures $6,17,20,21,24,26$. Previous researches showed adequate sealing ability, antimicrobial activity and biocompatibility for this material3,5,14-16,24,26. MTA is basically Portland cement with bismuth oxide added for radiopacity ${ }^{12,15}$. According to Camilleri (2007) the main components of Portland cement are: lime (CaO) $60-66 \%$, silica
$\left(\mathrm{SiO}_{2}\right)$ 19-25\%, alumina $\left(\mathrm{Al}_{2} \mathrm{O}_{3}\right) 3-8 \%$, and ferric oxide $\left(\mathrm{Fe}_{2} \mathrm{O}_{3}\right) 1-5 \%$. Portland cement is manufactured by means of a clinkering process of the unprocessed materials. Composition of Portland cement clinker is: $55 \%$ tricalcium silicate, $20 \%$ dicalcium silicate, $10 \%$ tricalcium aluminate and $10 \%$ tetracalcium aluminoferrite ${ }^{11,18}$. The components of Portland cement produce calcium hydroxide and a silicate hydrate gel during hydration, these composites possibly being responsible for the biocompatibility of the cement ${ }^{8-10}$. This performance has been previously assessed in implantation tests ${ }^{25,27}$, cell 
culture tests 22,29 , and in human and animal direct pulp capping procedures $17,20,21,23$. These studies showed similar results for Portland cement and MTA.

In the cement production process, gypsum is added to the Portland cement clinker in amounts of $3-6 \%$ to delay the setting time. The exclusion of gypsum in the final stage of Portland cement production showed decrease of the setting time of the cement ${ }^{8}$. Significant reduction in setting time is helpful in clinical procedures because MTA exhibits a longer setting time $2,4,5,19$. The Portland cement clinker has advantageous properties, such as an adequate setting time, alkaline $\mathrm{pH}$ and calcium release ${ }^{28}$. The aim of this study was to evaluate the subcutaneous tissue response of white Portland cement clinker with $2 \%$ and $5 \%$ calcium sulfate. The setting time of each material was also evaluated.

\section{MATERIAL AND METHODS}

The materials used in this study were: White Portland cement clinker without calcium sulfateWPCC (Grupo Votorantim, Itaboca, MG, Brazil), WPCC with $2 \%$ or $5 \%$ calcium sulfate (Carlo Erba Reagents, Italia) and MTA-CPM (EGEO SRL, Buenos Aires, Argentina). White Portland cement clinker was sieved under laboratory conditions to a particle size of 0.062 mm (Bronzinox, São Paulo, SP, Brazil). The materials were mixed using a spatula and glass plate and the powder/liquid ratio used for all tested materials was in the $3: 1$ ratio.

\section{Biocompatibility test}

Twenty-four adult male Wistar rats (Rattus norvegicus albinus) weighing between 200-250 $\mathrm{g}$ were used for this experiment after approval by the institutional Ethics Committee for Animal Research. The animals were anesthetized with an intramuscular dose of $25 \mathrm{mg} / \mathrm{kg}$ ketamine chloride and $10 \mathrm{mg} / \mathrm{kg}$ xylazine chloride, and then four incisions were made through the dorsal skin using a \#5 scalpel blade. A blunt dissecting instrument was used to create a $20 \mathrm{~mm}$ deep pocket in the subcutaneous tissue to receive the implants. Polyethylene tubes ( $1 \mathrm{~mm}$ diameter and $10 \mathrm{~mm}$ length) were previously sterilized and filled with the tested materials. Each animal received four implants with the different tested materials. The wounds were closed and sutures were removed after 7 days.

Eight animals were used for each evaluated period (15, 30 and 60 days). The animals were killed by an intracardiac anesthetic injection. Subcutaneous tissues with the implanted tubes were removed and immediately placed in $10 \%$ formalin. After histological procedures, $5 \mu \mathrm{m}$-thick serial sections were prepared and stained with hematoxylin and eosin.
The subcutaneous response of the tissue in direct contact with the cements (capsule) was evaluated using descriptive parameters and by morphometric analyses of the inflammatory cells using an optical microscope (Leitz, Aristoplan, Germany). The counting procedure was done at a total magnification of $1000 \mathrm{X}$. The system consisted of a square frame of definite size enclosing a network of test lines crossed to form 25 volumetric points. For this procedure, 3 slices with 4 semi-serial sections were selected for the analyses. In each section, five operative fields were selected for the morphometric procedure. In each point $(\mathrm{Pi})$, the presence of inflammatory cells was registered, and cell density was determined by dividing the total number of points analyzed $(P)$ by the number of points that include the histological structure.

The inflammatory response was also evaluated by semi-quantitative analysis at 400X and scored as: 0: without inflammation cells (no reaction); 1 : $<25$ inflammatory cells (mild reaction); 2: 25-125 inflammatory cells (moderate reaction); $3:>125$ inflammatory cells (severe reaction). KruskalWallis and Dunn tests were used to determine the significant differences of the inflammatory response of the test materials $(p<0.05)$.

\section{Setting time test}

Setting time of the materials was measured under controlled temperature and humidity $\left(37 \pm 1^{\circ} \mathrm{C}\right.$ and $95 \pm 5 \%$ relative humidity), according to the ASTM specification Number C266-08 guideline. The materials were mixed and inserted in metallic ring molds (10 $\mathrm{mm}$ diameter and $2 \mathrm{~mm}$ thick). Three specimens of each cement were made. After 180 $\mathrm{s}$, each specimen was indented using a $113.5 \mathrm{~g}$ Gilmore needle for determining initial setting time. Final setting time was obtained using a $456.5 \mathrm{~g}$ Gilmore needle. Data were subjected to statistical analysis using ANOVA and Tukey test for multiple comparisons $(p<0.05)$.

Table 1- Mean scores attributed to the inflammatory cells (IC) adjacent to implanted material surface in the 15, 30 and 60 days periods

\begin{tabular}{|c|c|c|c|}
\hline & $15 d$ & $30 \mathrm{~d}$ & $60 \mathrm{~d}$ \\
\hline CPM-MTA & 2 & 1 & 0 \\
\hline Clinker & 2 & 0 & 0 \\
\hline $\begin{array}{l}\text { Clinker }+2 \% \\
\mathrm{CaSO}_{4}\end{array}$ & 1 & 1 & 0 \\
\hline $\begin{array}{l}\text { Clinker }+5 \% \\
\mathrm{CaSO}_{4}\end{array}$ & 2 & 1 & 0 \\
\hline
\end{tabular}




\section{RESULTS}

\section{Microscopic analysis}

Table 1 shows the mean scores attributed to the inflammatory cells of the evaluated groups. Table 2 shows the results of morphometric analysis adjacent to the implanted material surface at 15 , 30 and 60 days.

\section{5 days}

Tissue response for all cements was very similar in this period. Among the main characteristics, it was observed a fibrous capsule formation outlining the polyethylene tube. The capsule was thick, with collagen fibers arranged around the cement. There were a large number of fibroblasts, showing high synthetic activity. This area also presented small blood vessels and few inflammatory cells with no statistically significant differences among the materials $(p>0.05)$.

\section{0 days}

Tissue response was similar to the 15 days period. However, more organized capsules were found with collagen fibers arranged parallel to the cement, containing few fibroblasts and inflammatory cells, predominantly macrophages. Collagen fibers were thicker, blood vessels less numerous and there was fewer empty spaces than in the 15-day-period, indicating a better degree of tissue organization. There were no statistically significant differences among the materials ( $p>0.05)$.

\section{0 days}

The tissue showed a thick fiber structure positioned parallel to the cement surface. There were few fibroblasts, little visualization of other structures, decreasing in quantity. There were few blood vessels and absence of inflammatory cells. There were no statistically significant differences among the materials ( $p>0.05)$. Representative images of the tested materials are shown in Figure 1.

In a general way, blood vessels decreased when compared to shorter periods, demonstrating a better organization and tissue maturation with time. A thin fibrous capsule, with few chronic inflammatory cells (macrophages, lymphocytes and multinucleated giant cells) circumscribed the

Table 2- Mean of density volume (\%) and standard deviation of inflammatory cells shown in connective tissue (capsule) adjacent to the implanted pure clinker, $2 \%$ calcium sulfate clinker; $5 \%$ calcium sulfate clinker; CPM (MTA-Egeo)

\begin{tabular}{lccc}
\hline & $\mathbf{1 5} \mathbf{d}$ & $\mathbf{3 0} \mathbf{d}$ & $\mathbf{6 0} \mathbf{d}$ \\
\hline CPM-MTA & $0.40(0.26)$ & $0.21(0.14)$ & $0.19(0.15)$ \\
Clinker & $0.59(0.33)$ & $0.15(0.11)$ & $0.17(0.13)$ \\
Clinker+2\% CaSO & $0.30(0.18)$ & $0.29(0.11)$ & $0.18(0.16)$ \\
Clinker+5\% CaSO $_{4}$ & $0.47(0.27)$ & $0.33(0.12)$ & $0.18(0.09)$ \\
\hline
\end{tabular}
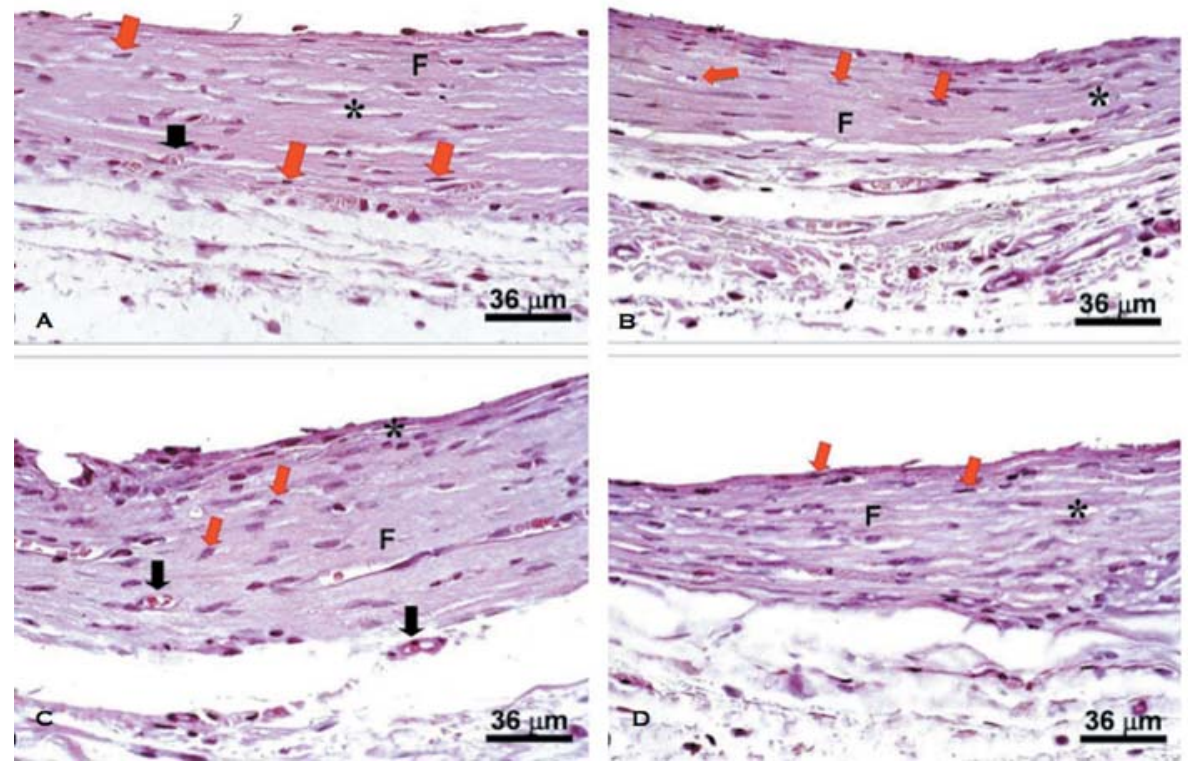

Figure 1- Subcutaneous tissue response at 60 days at capsular tissue $\left(^{*}\right)$. Pure clinker cement (A), White Portland cement clinker with $2 \%(B)$ or $5 \%$ calcium sulfate (C) and MTA-CPM (D). Presence of collagens fibers arranged parallel to the cement $(F)$, fibroblasts (red arrows), vessels (black arrows) and absence of inflammatory cells 
Table 3- Mean of initial and final setting times, values expressed in minutes (') and seconds (')

\begin{tabular}{ccc}
\hline Material & $\begin{array}{c}\text { Initial setting } \\
\text { time }\end{array}$ & $\begin{array}{c}\text { Final setting } \\
\text { time }\end{array}$ \\
\hline MTA & $15^{\prime} 01^{\prime \prime}$ & $27^{\prime} 36^{\prime \prime}$ \\
Clinker & $6^{\prime} 18^{\prime \prime}$ & $21^{\prime} 48^{\prime \prime}$ \\
Clinker+2\% & 9 9'22" & $25^{\prime} 33^{\prime \prime}$ \\
CaSO $_{4}$ & & \\
Clinker+5\% $_{\text {CaSO }}$ & $10^{\prime} 06^{\prime \prime}$ & $42^{\prime} 46^{\prime \prime}$ \\
\hline
\end{tabular}

material in the 15 days period. The number of these cells decreased in the 30 and 60 days periods.

\section{Setting time}

The initial and final setting times for all materials are shown in Table 3. Clinker without calcium sulfate showed the shortest initial and final setting times $(6.18 \mathrm{~s} / 21.48 \mathrm{~s})$, followed by clinker with $2 \%$ calcium sulfate $(9.22 \mathrm{~s} / 25.33 \mathrm{~s})$, clinker with $5 \%$ calcium sulfate (10.06 s/42.46 s) and MTA (15.01 $\mathrm{s} / 42.46 \mathrm{~s})$. Regarding the initial setting time, MTA showed a significantly higher setting time $(p<0.05)$ than the other materials. Only the addition of $5 \%$ calcium sulfate increased significantly $(p<0.05)$ the setting time compared with pure clinker. For the final setting time, the clinker with $5 \%$ calcium sulfate showed significantly higher time compared with the other materials. Another significant difference $(p<0.05)$ was observed in the comparison of pure clinker and MTA.

\section{DISCUSSION}

This study evaluated the setting time and the subcutaneous tissue response to the white Portland cement clinker with or without $2 \%$ and $5 \%$ calcium sulfate. Clinically, some situations such as retrograde filling and sealing of perforation, require a faster setting time to avoid the dissolution of the components by blood or tissue fluids. In these situations, the use of MTA without calcium sulfate (Portland cement clinker) could be more advantageous. The results showed that all tested materials presented a similar behavior with small differences regarding to the evaluated periods. In the literature review were found no biocompatibility in vivo studies about the white Portland cement clinker with or without calcium sulfate in different proportions. The biocompatibility of MTA and Portland cement was verified by several studies and is basically attributed to calcium hydroxide formation after hydration ${ }^{10,12,17 .}$

The biocompatibility of MTA is related to its capacity of releasing calcium ions and, consequently, to the alkaline $\mathrm{pH}$ produced by the material.
When exposed to a humid medium, MTA releases calcium silicate and calcium oxide. The calcium oxide released produces calcium hydroxide after reacting with the tissue fluids, which in turn release calcium ions. Calcium ions are important for their participation in the activation of calcium-dependent adenosine triphosphatase. Calcium carbonate from the reaction of calcium ion with carbon dioxide crystals acts as a nucleus for calcification and favors the mineralization. A rich extracellular network of fibronectin in close contact with these crystals strongly supports the role of calcite crystals and fibronectin as an initial step in the formation of hard tissue. Although this calcium ion release promoted by MTA contributes to turning the medium inhospitable for bacterial growth, its high concentration after hydration might contribute to the fibrosis of adjacent tissues ${ }^{1,15,28}$.

Regarding the setting time, previous studies have shown an initial setting time of 40 min for MTA ProRoot and 12 min for MTA-Angelus ${ }^{13,18}$. MTA final setting times reported are: $140-170 \mathrm{~min}^{13,18,26}$ and Portland cement initial and final setting times were $70 \mathrm{~min}$ and $170 \mathrm{~min}^{18}$ respectively. It was observed that the Portland cement clinker without calcium sulfate exhibited the smallest initial setting time $(6.18 \mathrm{~min})$ followed by Portland cement clinker with $2 \%$ calcium sulfate $(9.22 \mathrm{~min})$, and Portland cement clinker with $5 \%$ calcium sulfate (10.06 $\mathrm{min})$. The results of setting time of white Portland cement clinker are similar to the results reported by Camilleri, et al. ${ }^{10}$ (2005) who reported initial and final setting times of 5 and 8 min.

In conclusion, the inflammatory responses of white Portland cement clinker with or without $2 \%$ or $5 \%$ calcium sulfate and MTA Egeo were similar when they were implanted in subcutaneous tissue for 15, 30 and 60 days. White Portland cement clinker without calcium sulfate presented the shortest initial setting time. The $2 \%$ and $5 \%$ calcium sulfate clinkers showed intermediary setting times while MTA showed the longest. Calcium sulfate delayed the white Portland cement clinker setting time.

\section{REFERENCES}

1- Aguilar FG, Garcia LFR, Pires-de-Souza FCP. Biocompatibility of new calcium aluminate cement (EndoBinder). J Endod. 2012;38:367-71.

2- Al Anezi AZ, Zhu Q, Wang YH, Safavi KE, Jiang J. Effect of selected accelerants on setting time and biocompatibility of mineral trioxide aggregate (MTA). Oral Surg Oral Med Oral Pathol Oral Radiol Endod. 2011;111:122-7.

3- Al Hiyasat AS, Al Sa'Eed OR, Darmani H. Quality of cellular attachment to various root-end filling materials. J Appl Oral Sci. 2012;20:82-8.

4- Ber BS, Hatton JF, Stewart GP. Chemical modification of ProRoot MTA to improve handling characteristics and decrease setting time. J Endod. 2007;33:1231-4. 
5- Bortoluzzi EA, Broon NJ, Bramante CM, Garcia RB, Moraes IG, Bernardineli N. Sealing ability of MTA and radiopaque Portland cement with or without calcium chloride for root-end filling. J Endod. 2006;32:897-900.

6- Broon NJ, Bramante CM, Assis GF, Bortoluzzi EA, Bernardineli N, Moraes IG, et al. Healing of root perforations treated with Mineral Trioxide Aggregate (MTA) and Portland cement. J Appl Oral Sci. 2006; 14:305-11.

7- Camilleri J. Hydration mechanisms of mineral trioxide aggregate. Int Endod J. 2007;40:462-70.

8- Camilleri J. Characterization of hydration products of mineral trioxide aggregate. Int Endod J. 2008;41:408-17.

9- Camilleri J, Montesin FE, Brady K, Sweeney R, Curtis RV, Pitt Ford TR. The constitution of mineral trioxide aggregate. Dent Mater. 2005;21:297-303.

10- Camilleri J, Montesin FE, Di Silvio L, Pitt Ford TR. The chemical constitution and biocompatibility of accelerated Portland cement for endodontic use. Int Endod J. 2005;38:834-42.

11- Camilleri J, Montesin FE, Juszczyk AS, Papaioannou S, Curtis RV, Donald FM, et al. The constitution, physical properties and biocompatibility of modified accelerated cement. Dent Mater. 2008;24:341-50.

12- Camilleri J, Pitt Ford TR. Mineral trioxide aggregate: a review of the constituents and biological properties of the material. Int Endod J. 2006;39:747-54.

13- Chng HK, Islam I, Yap AU, Tong YW, Koh ET. Properties of a new root-end filling material. J Endod. 2005;31:665-8.

14- Cunha AS, Rached FJ Jr, Alfredo E, León JE, Perez DE. Biocompatibility of sealers used in apical surgery: a histological study in rat subcutaneous tissue. Braz Dent J. 2011;22:299-305. 15- Estrela C, Bammann LL, Estrela CR, Silva RS, Pécora JD. Antimicrobial and chemical study of MTA, Portland cement, calcium hydroxide paste, Sealapex and Dycal. Braz Dent J. 2000;11:3-9. 16- Gonçalves JL, Viapiana R, Miranda CE, Borges AH, Cruz Filho AM. Evaluation of physico-chemical properties of Portland cements and MTA. Braz Oral Res. 2010;24:277-83.

17- Holland R, Souza V, Murata SS, Nery MJ, Bernabé PF, Otoboni Filho JA, et al. Healing process of dog dental pulp after pulpotomy and pulp covering with mineral trioxide aggregate or Portland cement. Braz Dent J. 2001;12:109-13.
18- Islam I, Chng HK, Yap AU. Comparison of the physical and mechanical properties of MTA and Portland cement. J Endod. 2006;32:193-7.

19- Kogan P, He J, Glickman GN, Watanabe I. The effects of various additives on setting properties of MTA. J Endod. 2006;32:569-72. 20- Menezes R, Bramante CM, Letra A, Carvalho VG, Garcia RB. Histologic evaluation of pulpotomies in dog using two types of mineral trioxide aggregate and regular and white Portland cements as wound dressings. Oral Surg Oral Med Oral Pathol Oral Radiol Endod. 2004;98:376-9.

21- Menezes R, Bramante CM, Garcia RB, Letra L, Carvalho VG, Carneiro $E$, et al. Microscopic analysis of dog dental pulp after pulpotomy and pulp protection with mineral trioxide aggregate and white Portland cement. J Appl Oral Sci. 2004;12:104-7.

22- Min KS, Kim HI, Park HJ, Pi SH, Hong CU, Kim EC. Human pulp cells response to Portland cement in vitro. J Endod. 2007;33:1636.

23- Nair PN, Duncan HF, Pitt Ford TR, Luder HU. Histological, ultrastructural and quantitative investigations on the response of healthy human pulps to experimental capping with mineral trioxide aggregate: a randomized controlled trial. Int Endod $\mathrm{J}$. 2008;41:128-50.

24- Parirokh M, Asgary S, Eghbal MJ, Stowe S, Eslami B, Eskandarizade $A$ et al. A comparative study of white and grey mineral trioxide aggregate as pulp capping agents in dog's teeth. Dent Traumatol. 2005;21:150-4.

25- Saidon J, He J, Zhu Q, Safavi K, Spångberg LS. Cell and tissue reactions to mineral trioxide aggregate and Portland cement. Oral Surg Oral Med Oral Pathol Oral Radiol Endod. 2003;95:483-9.

26- Torabinejad M, Chivian N. Clinical applications of mineral trioxide aggregate. J Endod. 1999;25:197-205.

27- Torabinejad M, Ford TR, Abedi HR, Kariyawasam SP, Tang HM. Tissue reaction to implanted root-end filling materials in the tibia and mandible of guinea pigs. J Endod. 1998;24:468-71.

28- Vivan RR, Zapata RO, Zeferino MA, Bramante CM, Bernardineli $N$, Garcia RB, et al. Evaluation of the physical and chemical properties of two commercial and three experimental root-end filling materials. Oral Surg Oral Med Oral Pathol Oral Radiol Endod. 2010;110:250-6.

29- Zhu Q, Haglund R, Safavi KE, Spangberg LS. Adhesion of human osteoblasts on root-end filling materials. J Endod. 2000;26:404-6. 